トピックス

\title{
多点電極アレイを用いた視細胞光応答の 複数点同時計測
}

本間耕平, 高橋政代 理化学研究所 網膜再生医療研究チ一ム

1.|はじめに

一般に，網膜変性疾患の検査では網膜電図（ERG， Electroretinogram）が，基礎研究でも臨床的にも広く用 いられている。しかし一般的な ERG では網膜全体の 機能を測定するため，網膜の局所的な応答を取得する ことができない，そのため，まず局所 ERG が開発さ れた ${ }^{1)}$ 。この方法ではバックグラウンドライト中の小 さなスポットライト刺激により黄斑部の局所的な ERGを取得することができる。ささらに続いて，モ二 ターを使ってのランダム光刺激を用いる多局所 ERG が開発された ${ }^{2)}$.これらによって大型動物に执いては 局所的な光応答が調べられるよらになった。 ただ，こ れら 2 つの方法はバックグラウンドライトの下で行わ れるため，錐体視細胞の応答のみしか得ることができ ない，また，光刺激が特殊であるため，網膜変性モデ ルとして有用なラット，マウスのような小さな動物で は困難であった。

本稿では，最近われわれが行った，多点電極アレイ による網膜光応答の測定法を紹介しつつ，今後に期待 される応用と課題について展望する.

\section{ERG の構成要素}

ERG では光刺激によっていくつかの典型的な波形 が測定される（図 1)。詳細な内容は他の解説書に委 ねるが 3)，“a-wave”は視細胞由来の波形であり，光伝 達シグナルによる暗電流の遮断に相当していると考え られている。“b-wave”は双極細胞およびミューラー グリア依存であるが，その由来については今なお議論 のあるところである.

“Oscillatory potential (OP)”の由来は明らかではな いが，アマクリン細胞，網膜神経節細胞，双極細胞の ネガティブフィードバック経路によると考えられてい る. 多点電極アレイを用いた光応答の測定でもこの ERG で得られるよらな波形が観察されるが，OP は見 られない(図 2)。また，b-waveはin vivoに比べて小

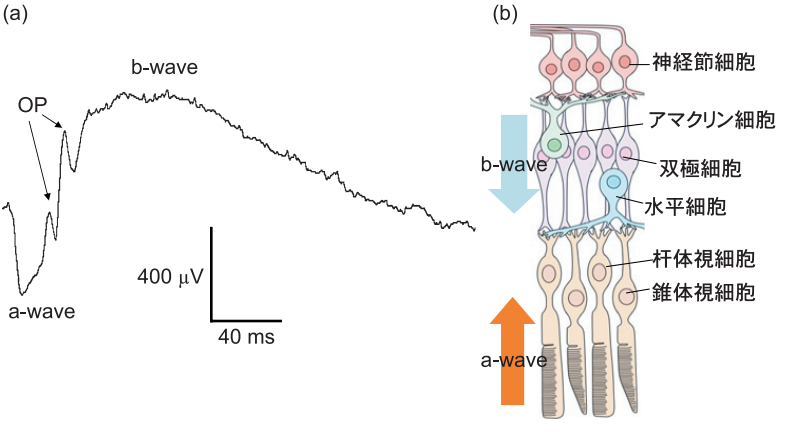

図 1

フラッシュ刺激による ERG.（a）ラットの ERG の例. 陰性波（awave), 振動波 (OP), 陽性波 (b-wave) が見られる.（b) a-wave は視細胞由来, b-wave は双極細胞依存である.（本図は, 冊子体 ではモノクロ, 電子ジャーナル http://www.jstage.jst.go.jp/browse/ biophys/-char/ja/ ではカラーで掲載)

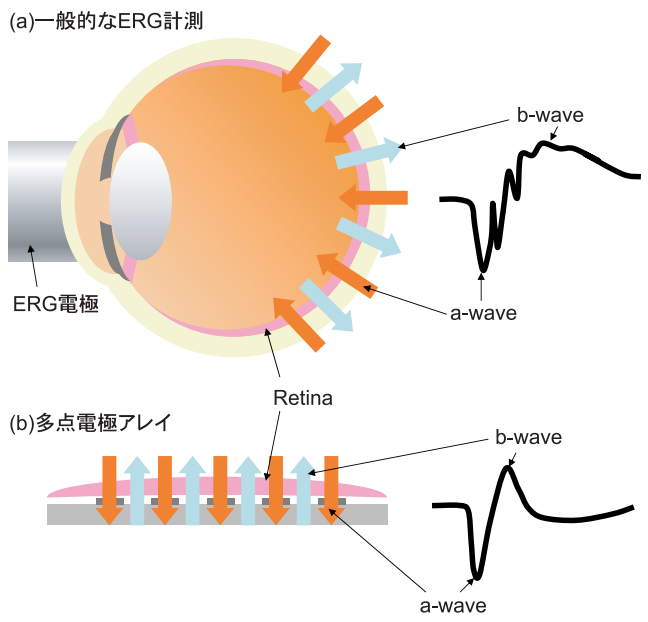

図 2

一般的な ERG の波形と多点電極アレイの光応答.（a）ERG で計測 される波形の方向性. (b) 多点電極アレイで計測される波形の方 向性. 硝子体側が電極に接しているとき ERG の向きに対応してい る.（本図は，冊子体ではモノクロ，電子ジャーナル http://www. jstage.jst.go.jp/browse/biophys/-char/ja/ ではカラーで掲載）

さく不安定で消失しやすい，一方で，a-wave は安定で 再現性がよい。これらの波形は多点電極アレイが硝子 体側網膜と接しているときに ERGの波形の方向に対 応していると考えられる。

Measurement of Light Responses in Photoreceptors by using Multi-Electrode Array

Kohei HOMMA and Masayo TAKAHASHI

Laboratory for Retinal Regeneration, Center for Developmental Biology, RIKEN 


\section{3. 多点電極アレイを用いた網膜神経活動計測}

多点電極アレイによる測定は，網膜の研究からはじ まり，おもに網膜神経節細胞のスパイク応答を計測す るために用いられてきた。 たとえば新生期の網膜にお いて網膜神経節細胞の神経活動が 2 次元的に伝播して ネットワークを形成していくことを明らかにした研 究 ${ }^{4)}$ や，最近では陰影刺激によって起こる網膜神経節 細胞群の周期的なバースト発火 ${ }^{5)}$, 網膜神経節細胞の スパイク応答の潜時によるコントラストの処理 ${ }^{6)}$ ぞ，網膜の平面並列処理機構を示す実験で利用されて きた。しかし，多点電極アレイで他の網膜細胞応答を 測定する試みは少なかった ${ }^{7)}$ 筆者らは多点電極アレ イによる ERG 測定を網膜変性モデルのラット，マウ スに適用し，特に視細胞の応答について解析を行っ た ${ }^{8)}$. N-methyl-N-nitrosourea（MNU）を投与した網膜 変性モデルラットで網膜周縁部位において視細胞の光 応答が残存していることがわかった（図 3, Central よ り Peripheral で a-wave が大きいことがわかる)。また網 膜組織への直接的な計測であるため，一般的な ERG では検出できない光応答を測定することができた.

\section{4. 網膜再生の評価に向けて}

現在，網膜前駆細胞を効率的に移植できることが網 膜変性モデルマウスにおいて明らかになってきてい る ${ }^{9)}$.しかし視機能の評価については必ずしも十分で はない. この原因の 1 つには一般的な ERG の測定限 界がある。ERGの測定は角膜を通して間接的に測定 するため，より直接的な多点電極アレイによる測定法 が有効であると考えられる。 また，ヒト ES 細胞から 分化させた網膜細胞を網膜変性モデルマウスに移植し て ERGの応答が回復したといら報告があるが 10）（先

(a)

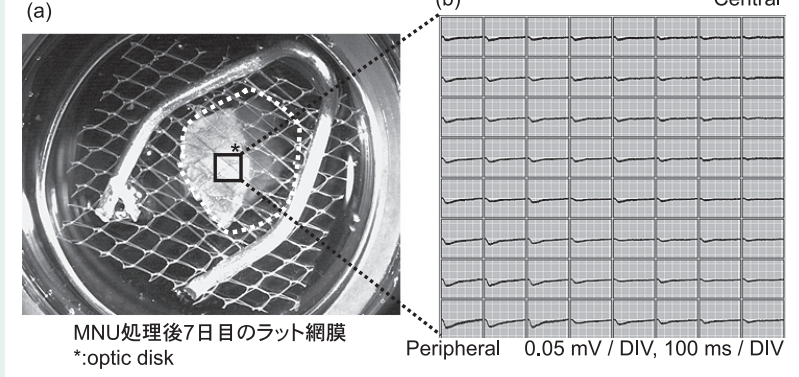

\section{図 3}

多点電極アレイによる光応答波形.（a）ラット網膜の光応答計測. MNU 処理 7 日目のラット網膜で計測した. 白点線は網膜全体. (b) 各電極に対応した光応答. 網膜の周縁部位で a-wave が確認 された.
の ERGの測定限界を考えると驚くべき結果である)， ERGの測定は網膜全体の応答を表しているので，移 植した細胞自体が光応答をしているかについては明ら かではない，多点電極アレイによる測定では，移植し た局所部位の光応答を確認でき，その効率の評価がで きる。

以上のように，多点電極アレイでは網膜の局所組織 に打ける視細胞，双極細胞，網膜神経節細胞の機能を 高感度に測定することが可能であり，マウス・ラット を用いた細胞移植，遺伝子治療などの研究において， 有用なツールになると考えられる。

文 献

1) Sandberg, M. A., Jacobson, S. G. and Berson, E. L. (1979) Am. J. Ophthalmol. 88, 702-707.

2) Sutter, E. E. and Tran, D. (1992) Vision Res. 32, 433-446.

3）山本修一, 新井三樹, 菅原岳史, 近藤峰生（2004）どうと る？どら読む？ ERG, メジカルビュー社.

4) Meister, M., Pine, J. and Baylor, D. A. (1991) Science 252, 939-943.

5) Ishikane, H., Gangi, M., Honda, S. and Tachibana, M. (2005) Nat. Neurosci. 8, 1087-1095.

6) Gollisch, T. and Meister, M. (2008) Science 319, 1108-1111.

7) Stett, A., Egert, U., Guenther, E., Hofmann, F., Meyer, T., Nisch, W. and Haemmerle, H. (2003) Anal. Bioanal. Chem. 377, 486-495.

8) Homma, K., Osakada, F., Hirami, Y., Jin, Z. B., Mandai, M. and Takahashi, M. (2009) J. Neurosci. Res. (in press)

9) MacLaren, R. E, Pearson, R. A., MacNeil, A., Douglas, R. H., Salt, T. E., Akimoto, M., Swaroop, A., Sowden, J. C. and Ali, R. R. (2006) Nature 444, 203-207.

10) Lamba, D. A, Gust, J. and Reh, T. A. (2009) Cell Stem Cell 4, 73-79.

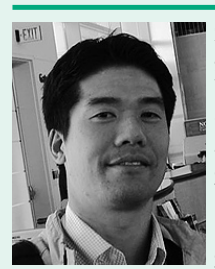

本間耕平（ほんま こうへい）

理化学研究所網膜再生医療研究チーム研究員

2008 年慶應義塾大学理工学研究科にて博士（理 学）学位取得, 同年に現職.

研究内容:細胞移植による網膜変性疾患治療技術 の開発および視機能の測定

連絡先: $=650-0047$ 兵庫県神戸市中央区港島南 本間耕平 町 2-2-3 理化学研究所 CDB

E-mail: homma@cdb.riken.jp URL: http://www.retinastem.jp/xoops/

高橋政代（たかはし まさよ）

理化学研究所網膜再生医療研究チームチームリー ダー

1986 年京大医学部卒業後, 眼科入局. 2006 年 まで京大眼科勤務. その間 1995-6 年アメリカ ソーク研究所留学, 2001 年京大病院探索医療セ ンター網膜再生研究チームリーダー. 06 年より 現職.

研究内容: 網膜変性疾患の診療とともに網膜細胞 移植の研究を行っている.

E-mail: mretina@cdb.riken.jp 